\title{
Geoelectrical Surveys for Characterization of the Coastal Saltwater Intrusion in Metapontum Forest Reserve (Southern Italy)
}

\author{
Antonio Satriani, Antonio Loperte, Vito Imbrenda, and Vincenzo Lapenna \\ Institute of Methodologies for Environmental Analysis, CNR, 85050 Tito, Italy \\ Correspondence should be addressed to Antonio Satriani, satriani@imaa.cnr.it
}

Received 25 May 2011; Revised 2 November 2011; Accepted 29 November 2011

Academic Editor: Sabatino Piscitelli

Copyright (c) 2012 Antonio Satriani et al. This is an open access article distributed under the Creative Commons Attribution License, which permits unrestricted use, distribution, and reproduction in any medium, provided the original work is properly cited.

A geoelectrical survey was carried out in the Metapontum Forest Reserve located along the Ionian coast of the Basilicata region (Southern Italy). In this work we used the method of two-dimensional electrical resistivity tomography for obtaining highresolution electrical images in the investigated site. In particular, three electrical resistivity tomography, all orthogonal to the coastline, in the investigated area were carried out. To complete and integrate the geophysical data, soil and groundwater samplings, seventeen and five, respectively, were analyzed using chemical physical techniques. Geoelectrical survey, supported by laboratory analysis of soil and water samples have revealed the presence of a process of saltwater in coastal Forest Reserve of Metapontum, which have caused the decline of the existing pine forest with the consequent erosion and desertification problems. The results have disclosed the way to identify and discriminate large areas affected by intensive soil salinization and high resolution electrical images of the subsurface electrical resistivity plays a key role in delineating the saltwater intrusion front in coastal areas. Furthermore, our integrated study represents a contribution to the future programs for the protection, planning, and management of the terrestrial and marine resources in this coastal area.

\section{Introduction}

Coastal areas are of great environmental, economic, social, and cultural relevance. Therefore, the implementation of suitable monitoring and protection actions is fundamental for their preservation and for assuring future use of this resource. Such actions have to be based on an ecosystem perspective for preserving coastal environment integrity and functioning and for planning sustainable resource management of both marine and terrestrial components (EU Recommendation on Integrated Coastal Zone ManagementICZM-European Commission EC/413/2002).

Post [1] has defined coastal aquifers as the subsurface equivalents of coastal areas where continental fresh groundwater and seawater meet. Coastal plains are often contaminated by salt waters and the process associated to the marine water entering an aquifer is generally called seawater intrusion. Different approaches have been adopted to esti- mate seawater intrusion. For example, many authors [2-5] have employed geochemical methods based on measures of electrical conductivity, of chloride concentration, and other cation and anion concentrations, parameters which generally highlight seawater contamination.

Nowadays great attention is focused on innovative geophysical methods for solving hydrogeological and environmental problems [6-10]. The geophysical methods for the subsurface exploration can contribute to the different phases of coastal environment characterization. Balia et al. [11] have applied a combination of geophysical techniques at the Muravera plain in southern Sardinia, Italy, which has been significantly affected by water salinization; Batayneh [12] used electrical resistivity methods for detecting subsurface fresh and saline water in the eastern Dead Sea coastal aquifers in Jordan; Bauer et al. [13] applied electrical resistivity tomography (ERT) to map the salinity distribution in the subsurface in the Okavango Delta, a large inland delta in 


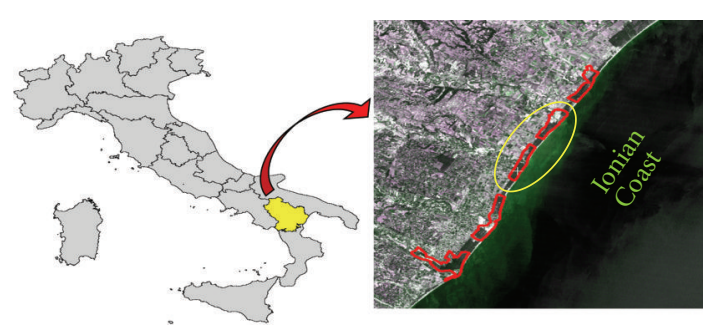

Figure 1: Location of the study area. The yellow ellipse highlights the natural reserve of Metapontum.

Botswana; while Koukadaki et al. [14] characterized the hydrogeology of a coastal aquifer using geophysical measurements and, in particular, electrical tomography. ERT, moreover, was applied to monitor seawater intrusion by Kruse et al. [15], Nowroozi et al. [16], Abdul Nassir et al. [17], and Sherif et al. [18]. Cimino et al. [19] carried out vertical electrical sounding in the coastal plain of Acquedolci (Northern Sicily- Italy) to assess seawater intrusion, while Khalil [20] applied a direct current resistivity geoelectric technique to delineate salt water intrusion from the Gulf of Suez. Moreover, Urish and Frohlich [21], Ebraheem et al. [22], and Choudhury and Saha [23] have performed geoelectrical surveys in different coastal area around the world.

In this paper we present the results of geoelectrical surveys, integrated with geochemical measurements, performed for the characterization of a coastal area along the Ionian side of the Basilicata region (Figure 1). This study area, located at the mouth of Bradano river (Metapontum, $40^{\circ} 22^{\prime} \mathrm{N}, 16^{\circ} 51^{\prime} \mathrm{E}$ ), is mainly interested by a narrow shore (10-30 $\mathrm{m}$ ) of fine sandy formations and has been affected by saltwater intrusion phenomena. This has caused the decline of the existing pine forest entailing significant ecological and environmental problems to the Metapontum Forest Reserve. Primary and secondary salinity of soil are linked to natural factors such as the climate, natural drainage patterns, topographic features, geological structure, distance to the sea, and by the indiscriminate exploitation of the soil and groundwater resources $[1,24,25]$.

In order to manage rightly this kind of problem, it is necessary to have a thorough knowledge of the phenomenon, and the first objective of this study is to identify, through the use of different techniques and methodology, salt intake as the factor concurring or even determining the serious phenomenon of total decline and the deterioration of vegetation in the pine forest.

The geoelectrical investigations and chemical-physical analysis were carried out, to evaluate the seawater intrusion effect. In particular, geoelectrical surveys allowed to assess the extent and depth of the saltwater intrusion process, while the chemical-physical characterization was performed by considering some soil properties such as $\mathrm{pH}$ values, salt contents measured as the electric conductivity (ECe), exchangeable sodium, and cation exchange capacity. Moreover, this study aims to better delineate the saltwater intrusion front and to support the environmental protection and regeneration programs carried out by local and national authorities for restoring the continuity of the woodland belt along the coast and consequently to obtain a reclassification of the landscape and protection of areas behind.

\section{Study Area}

The study area is located along the Ionian coastal plain, known as Metapontum plain. The area is made up of the regressive filling with marine sediments of a tectonic graben (Bradanic graben) during Pliocene to Pleistocene age. The area is bordered in the NE by the limestones of the Murgian foreland and in the SW by the clastic sediments of the Apennine chain. In the middle of the graben the full sedimentary sequence starts with sands, blue clays, covered by sands and gravels. The alluvial deposits in the estuarine environment are constituted of stratified sands to silty clays sediments. In this case, they are grey and very similar for aspect, but not for consistency, to the Pleistocene blue clays [4, 26, 27]. In particular, the Forest Reserve with an extent of about 240 hectares, situated in the north of the Ionian coastline between the mouth of rivers Bradano and Basento, is characterized by a superficial sandy substrate, and by clays and silts of river origin in the back dune zone (Figure 2).

The hydrogeology of the study area (Figure 3 ) is related to lithological and structural features of the same area, and they determine two types of aquifers.

An aquifer is constituted by marine terraces deposits and alluvial river valleys deposits, where the marine terraces aquifers show hydraulic conductivity from medium to high, equal or higher than the second type of aquifer constituted by coastal plain deposits.

The bottom of the this aquifer is a silty-clayey bed which lies under the sea level permitting the seawater intrusion, this phenomenon involves the coastal plain for a width of 1$1.5 \mathrm{~km}$ and it is less evident moving inwards where the altitude of the clayey bottom of the aquifer becomes progressively higher than the sea level [4].

The Metapontum coast is characterized by a strong erosive process. Marine erosion has really removed the dune behind the beach moving in the inland and causing the decline of the historical pinewood. Dunes and their vegetation are a natural defence against erosion by wind and sea and the variation of the line of the seashore is in close connection with the development of coastal dunes and their preservation [28]. Moreover, reduction of the coastal dune system in the study area facilitates the entry of salt water; dunes in fact, for their elevation and good infiltration capacity, give a sufficient freshwater recharge and a pressure above sea level, allowing hydrostatic control of saline intrusion [29].

Metapontum wooded strip is an artificial formation, planted in the first decade of the 50 s in order to preserve the coast and the inland cultivated areas from salt sea wind. The forest is composed of Aleppo pine trees (Pinus halepensis) and domestic pine trees (Pinus pinea) prevalently. Secondary species are acacia saligna (Acacia cianophylla) and eucalyptus (Eucalyptus globulus, E. camaldulensis), besides other species that are typical of Mediterranean scrub as Pistacia lentiscus, Juniperus macrocarpa and Juncos acutus, 


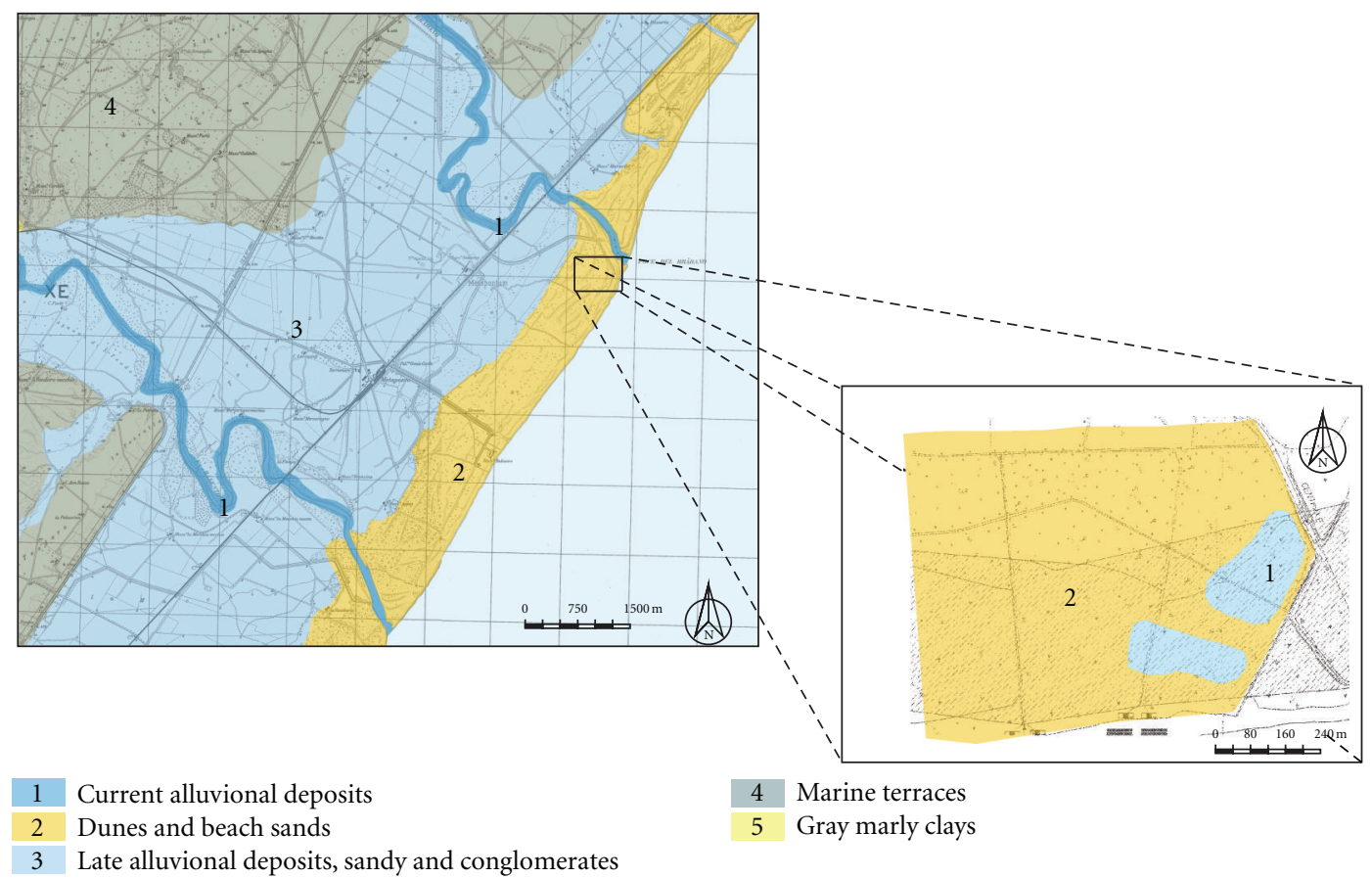

Figure 2: Geological map of the study area. (1) Current alluvional deposits; (2) dunes and beach sands; (3) late alluvional deposits sandy and conglomerates; (4) marine terraces; (5) gray marly clays.

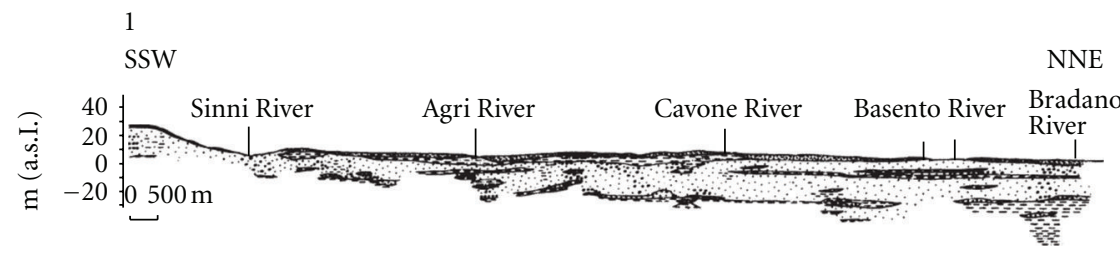

(a)

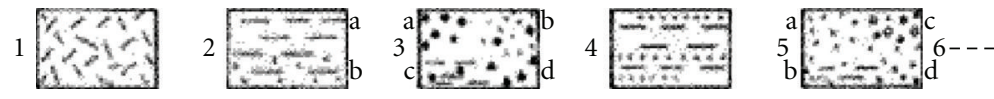

(b)

FIgURE 3: Schematic lithological section [4]. Legend: (1) soil; (2) clays or silty clays (yellow, brown, grey; (a)) locally sandy clays (b); (3) pebbles (a) in a sandy (b) or clayey matrix (c); pebbles locally cemented (d); (4) grey sands with clayey strata; (5) grey or yellow sands and silty sands (a), locally clayey sands (b) or with gravels (c), locally sandstone strata (d); (6) piezometric level.

often mixed with the type of vegetation which prefers sandy soil (called "psammofila"). The rearrangement of soil was done with the realization of "baulature," that is, elevation of soil in order to preserve tree roots from seawater intrusion.

On the basis of meteorological data, the climate of the area is semiarid with hot and dry summers; however, the evolution of the climate of the last period shows a trend to a reduction of annual precipitation and an increase in average temperatures [30].

\section{Field Investigations and Sampling}

In Figure 4 location of geoelectrical surveys and sampling points for chemical-physical analysis was indicated. The surveys have been performed during a geophysical campaigns carried out in July, and in this time of year the investigated area, classified as climatic type semiarid, is characterized by drought.

3.1. Geoelectrical Surveys. Resistivity measurements were conducted as tomographies to determine variations with depth in soil resistivity.

The surface electrical resistivity tomographies are a useful tool in determining seawater intrusion in coastal areas for its capability to discriminate the large resistivity contrast between the presence of seawater that strongly reduces the resistivity values and saturated freshwater layers. Moreover, in order to evaluate if this contrast is significant and does not depend on geological layer, a validation of the geoelectrical 


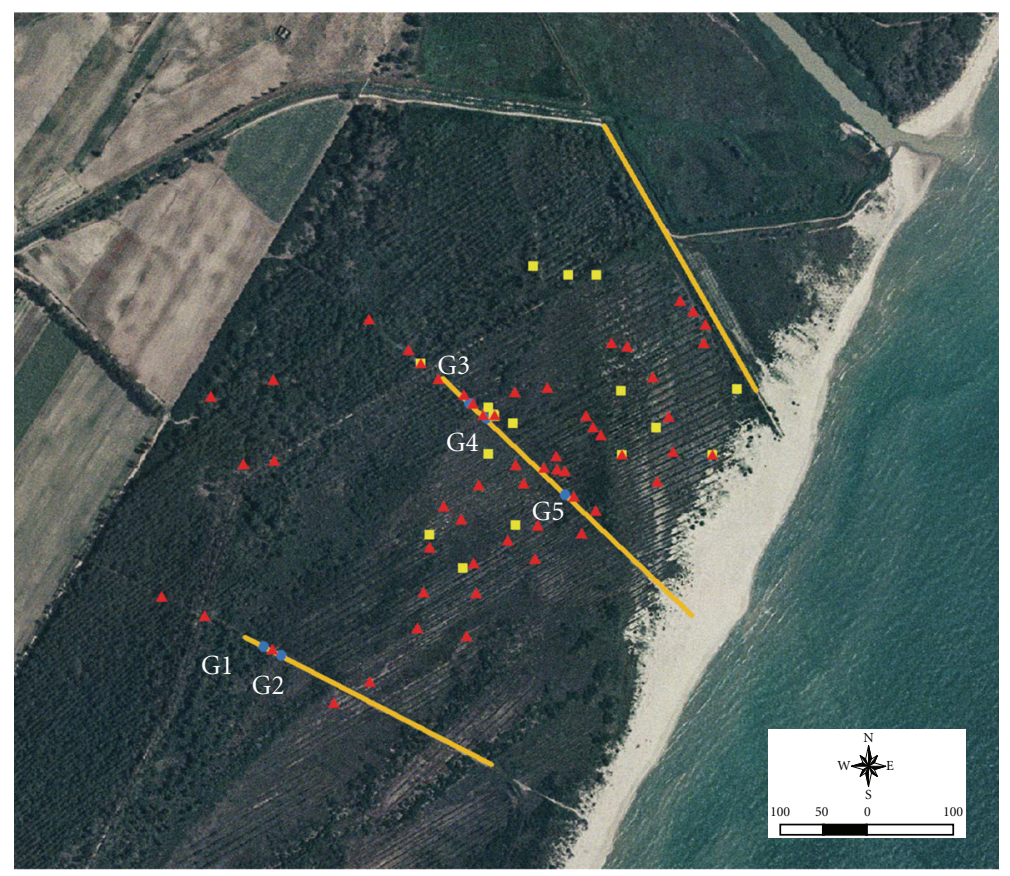

\footnotetext{
- Soil samples

- Water samples

ERT lines
}

FIgURE 4: Location map of geophysical surveys and sampling points.

measurements with some chemical-physical analysis of soil samples has been performed.

Three electrical resistivity tomographies (ERT) were obtained using the georesistivity meter Syscal R2 (Iris Instruments) connected to a multielectrode system. We used a Wenner-Schlumberger configuration array with electrodes spacing on the surface of 10.00 meters. The electrical tomographies were all orthogonal to the coastline.

The Wenner-Schlumberger array provided horizontal and vertical resolution, and to obtain 2D resistivity models the data obtained were interpreted through the inversion algorithm, RES2DINV, proposed by Loke [31]. The measured values of apparent resistivity provide, in fact, a first preliminary image of the electrical subsurface structure denominated as the "pseudosection". In a second step, the apparent resistivity measurements are transformed into true resistivity values using the rapid inversion algorithm of Loke and Barker [31].

The inversion routine is based on a smoothness-constrained least-squares method inversion algorithm that divides the subsurface into rectangular blocks, and the resistivity of the blocks is adjusted to minimize iteratively the difference between the computed and the measured apparent resistivity values; the root mean square (RMS) error gives a measure of this difference $[31,32]$.

3.2. Soil and Water Sampling. In addition, chemical and physical analyses on soil and water samples were performed in order to validate and integrate geophysical data. Undis- turbed soil samples, collected from the surface in the first $40 \mathrm{~cm}$ of soil using Soil Sample Ring Kits (Eijkelkamp Equipment Netherlands), were taken for chemical analyses, using standard analytical procedures (Official Gazette of Italy No 248 of 21 October 1999). Soil samples were analyzed for $\mathrm{pH}$ (in water and in $\mathrm{CaCl}_{2}$ ), for cations $(\mathrm{Na}, \mathrm{K}, \mathrm{Ca}$, and $\mathrm{Mg}$ ), for sulphates, chlorurs and nitrates, for organic matter and organic carbon, for cation exchange capacity, for an electrical conductivity of a saturated paste extract (ECe) or its inverse, electrical resistivity, and for texture. Groundwater samples were collected from few shallow holes across the area, since the groundwater table in the study area was high.

\section{Results}

The $2 \mathrm{D}$ resistivity results obtained by the inversion algorithm performed with the software RES2DINV are shown as images in Figure 5.

Electrical resistivity values are related to geological parameters of the subsurface and, in particular, resistivity values are controlled by the types of rocks and fluid. Then, the high-resolution electrical images are a powerful tool to identify conductive zones for the saltwater intrusion phenomena. Figure 5 shows the three 2D electrical images obtained in the study area related with depth and true resistivity of the subsoil investigated.

ERT 1 with direction NNW towards SE obtained on a rather flat regular surface, showed a first zone in the shallow part with values of $5-15 \Omega \mathrm{m}$ which could be associated with 


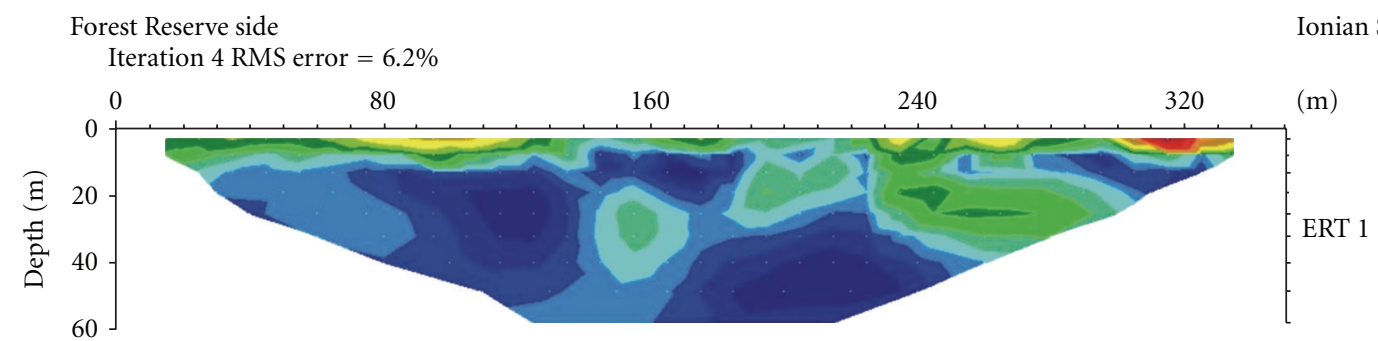

(a)

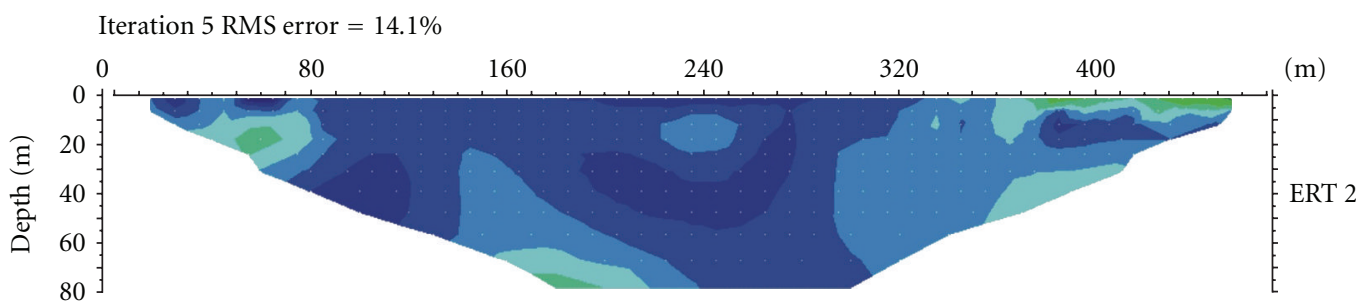

(b)

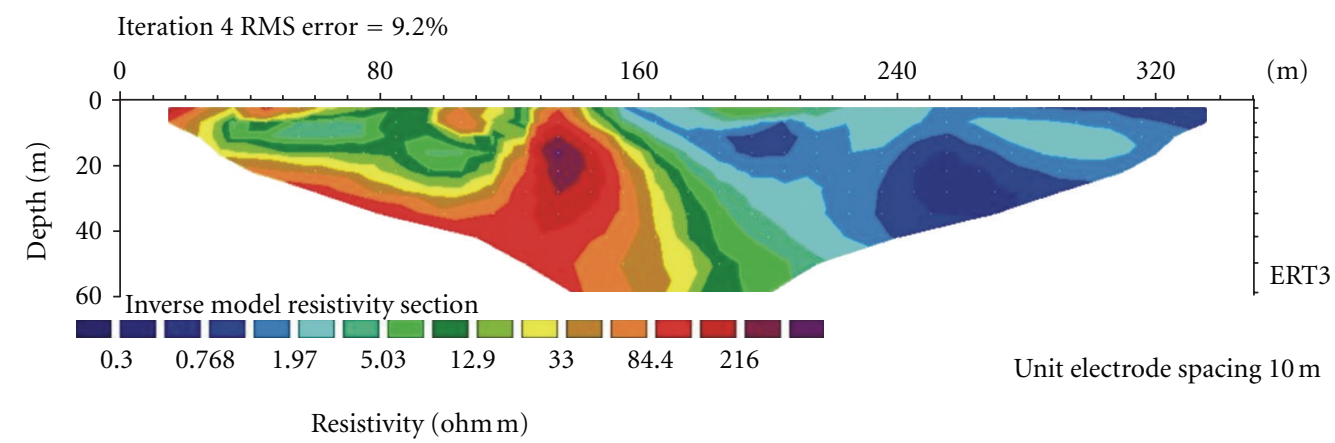

(c)

FIGURE 5: 2D electrical resistivity tomographies obtained in the investigated site. The position of each ERT is shown in Figure 3.

TABLE 1: Minimum and maximum values of chemical-physical data of soil samples collected in the study area.

\begin{tabular}{lc}
\hline Parameters & $\begin{array}{c}\text { Minimum and } \\
\text { Maximum Values }\end{array}$ \\
\hline $\mathrm{Na}\left(\mathrm{mg} \mathrm{kg}^{-1}\right)$ & $626-3425$ \\
$\mathrm{~K}\left(\mathrm{mg} \mathrm{kg}^{-1}\right)$ & $162-960$ \\
$\mathrm{Ca}\left(\mathrm{mg} \mathrm{kg}^{-1}\right)$ & $917-2830$ \\
$\mathrm{Mg}\left(\mathrm{mg} \mathrm{kg}^{-1}\right)$ & $203-905$ \\
$\mathrm{Nitrogen}\left(\mathrm{g} \mathrm{kg}^{-1}\right)$ & $0.6-1.4$ \\
Organic carbon $\left(\mathrm{g} \mathrm{kg}^{-1}\right)$ & $4.9-21.5$ \\
Organic matter $\left(\mathrm{g} \mathrm{kg}^{-1}\right)$ & $8.4-37.1$ \\
$\mathrm{pH}\left(\mathrm{H}_{2} \mathrm{O}\right)$ & $8.6-9.8$ \\
$\mathrm{pH}\left(\mathrm{CaCl}{ }_{2}\right)$ & $7.9-8.9$ \\
Electrical conductivity $(\mathrm{ECe})($ Siemens & $0.153-1.484$ \\
$\left.\mathrm{~m}^{-1}\right)$ & $6.536-0.674$ \\
Electrical resistivity $(\Omega \mathrm{m})$ & $7.4-17.2$ \\
Cation exchange capacity $(\mathrm{meq} / 100 \mathrm{gr})$ & $162-5894$ \\
Chlorurs $\left(\mathrm{mg} \mathrm{kg}^{-1}\right)$ & $<0.1$ \\
Nitrate $\left(\mathrm{mg} \mathrm{kg}^{-1}\right)$ & $15.3-441$ \\
Sulphate $\left(\mathrm{mg} \mathrm{kg}^{-1}\right)$ & $33.3-85.2$ \\
Sand \% & $7.1-35.7$ \\
Silt \% & $7.5-38.2$ \\
Clay \%
\end{tabular}

a layer filled with inert material, and a second one with lower resistivity values $(\rho<1.5 \Omega \mathrm{m})$ reflecting saturated strata.

ERT 2 is nearly parallel to the direction of ERT 1, it runs from NW to SE. As shown in Figure 5, the geoelectrical image presents a lateral variation in resistivity distribution, with higher electrical resistivity values (about $1-10 \Omega \mathrm{m}$ ) towards $\mathrm{SE}$ in the first part of the section (between 0 and $110 \mathrm{~m}$ ). Lower electrical resistivity values were observed towards sea side, and these values reduced are maybe due to saturated strata for a subsurface seawater flow zone.

ERT 3 in direction of WNW-SE shows a significant trend of resistivity, in fact, the resistivity section is characterized by two zones with different resistivity values: the first zone, towards the inland of the Forest Reserve and throughout the thickness of soil explored, shows moderate to high resistivity values $10-220 \Omega \mathrm{m}$, while the second zone, towards the sea, shows very low resistivity values.

As expected, the 2D electrical resistivity tomographies show that resistivity values decrease in depth and from inland towards the Ionian Sea.

We have checked, one by one, the apparent resistivity values obtained during the field survey, and the topographic correction has been introduced. Only the apparent resistivity 
TABLE 2: Electrical proprieties and $\mathrm{pH}$ values of groundwater samples.

\begin{tabular}{lccc}
\hline Samples & $\mathrm{pH}$ & Electrical conductivity $(\mathrm{ECe})$ Siemens $\mathrm{m}^{-1}$ to $25^{\circ} \mathrm{C}$ & Electrical resistivity $\Omega \mathrm{m}$ \\
\hline $\mathrm{G} 1$ & 7.7 & 0.68 & 1.470 \\
$\mathrm{G} 2$ & 7.7 & 0.81 & 1.234 \\
$\mathrm{G} 3$ & 7.8 & 1.92 & 0.520 \\
$\mathrm{G} 4$ & 7.3 & 2.92 & 0.342 \\
G5 & 7.5 & 7.27 & 0.137 \\
Sea water & 8.2 & 5.66 & 0.176 \\
\hline
\end{tabular}

measurements affected by a standard deviation lower than $5 \%$ have been considered. In a second step we have increased the number of iterations of the inversion software routine. After this procedure the RMS of the electrical imaging is lower than $15 \%$. If we take into account the strong variability of the resistivity values from $\sim 1000 \Omega \mathrm{m}$ for sandy layers to $\sim 1 \Omega \mathrm{m}$ of fully saltwater saturated zones, this error can be considered acceptable.

We used the RES2DINV, that is, a well-assessed algorithm for $2 \mathrm{D}$ resistivity data inversion, and there is a large scientific literature in which the RMS of the $2 \mathrm{D}$ electrical imaging is greater than $10 \%$. Electrical imaging of complex geological environments are generally affected by RMS greater than $15 \%[10,33]$ and in many cases is not possible to reduce the RMS without introducing artifacts.

In literature, salt water resistivity values below $1.0 \Omega \mathrm{m}$ were reported, in fact, seawater has an average resistivity of $0.2 \Omega \mathrm{m}[16,34]$, while the resistivity of a layer saturated by saline water and dissolved solids is in the range of 8 to $50 \Omega \mathrm{m}$ $[13,16,35,36]$. Therefore, based on these values of resistivity of layers saturated by saline water and some dissolved solids reported in the literature, resistivity data obtained in this work from geoelectric investigations, highlight the presence of strata saturated with seawater.

In Tables 1 and 2 the results of laboratory analysis for the physical and chemical parameters of soil and groundwater samples were summarised. Laboratory analyses permit to suppose that high $\mathrm{pH}$ values are determined by the accumulation of sodium and magnesium on the soil exchange complex. In fact, in the study area, $\mathrm{pH}$ values (in $\mathrm{CaCl}_{2}$ ) have a range between 7.9 and 8.9 in soil samples, and between 7.3 and 7.8 in groundwater samples. A sample of sea water, instead, reported $\mathrm{pH}$ value of 8.2. Important differences were resulted in the conductivity (ECe) expressed in Siemens $\mathrm{m}^{-1}$ or its inverse, electrical resistivity, expressed in $\mathrm{Ohmm}$. The mean ECe value on soil samples was equal to 0.613 Siemens $\mathrm{m}^{-1}$, corresponding to $1.631 \Omega \mathrm{m}$ with a range from 0.153 to 1.484 Siemens $\mathrm{m}^{-1}$, equal to a range of resistivity from 6.536 to $0.674 \Omega \mathrm{m}$ while in water samples the mean ECe value was equal to 2.720 Siemens $\mathrm{m}^{-1}$, corresponding to $0.368 \Omega \mathrm{m}$, and with a range from 0.68 to 7.27 Siemens $\mathrm{m}^{-1}$, equal to a range of resistivity from 1.470 to $0.137 \Omega \mathrm{m}$.

On the other hand, in seawater samples ECe value was equal to 5.660 Siemens $\mathrm{m}^{-1}$, corresponding to $0.177 \Omega \mathrm{m}$. Furthermore, the major ions were $\mathrm{Na}^{+}, \mathrm{Ca}^{2+}$, and $\mathrm{Cl}^{-}$. Therefore, according to the classification NRCS [37], the area investigated presents from inland to coast, zones slightly saline, zones moderately saline, and zones close to highly saline. The high concentration of soluble salts determines high osmotic pressure that makes very difficult to absorb water and nutrients from the roots of plants, creating the limiting factor to the diffusion and survival of forest species. The salinity distribution in the subsurface of study area is reflected by the vegetation cover, in fact, the zone with soil salinity is covered by salt-tolerant grasses [30]. On the basis of the geoelectrical measurements and of the chemicalphysical analysis, the presence of zones with very low electrical resistivity values, can be associated to the intrusion of salt water into the subsoil. In the coastal environment, like the study area, hydraulic connection with seawater and inland gradient that move water to inland from seawater source, are such conditions as to cause seawater intrusion [2].

\section{Conclusions}

Geoelectrical surveys reveal the presence of two principal zones characterized by different resistivity values. The former is a strip back dune, closer to the sea, with a higher clay content and located at an altitude below sea level. It is submerged during the winter by water for a poor drainage, and it is characterized by lower resistivity values. The second zone is characterized by higher resistivity values and has a quite good vegetative cover for the best environmental conditions, greater distance from the sea, and elevation above sea level. In this area the spontaneous emergence of new plant pine is frequently observed for the fact that soil conditions are favourable as there is no seawater intrusion yet.

Results presented in this paper showed that the process of salt water is active on coastal Forest Reserve of Metapontum, and geoelectrical surveys have proved to be precious tools. Geoelectrical surveys have highlighted significant variations in subsurface resistivity associated with lithological characteristics of underground layers and variations in water saturation. In particular, these surveys have produced images of resistivity of the soil investigated, where the spatial distribution of brackish and saline water in the pine forest and resistivity variation with depth is very clear. These observations are also confirmed from laboratory analysis on soil and groundwater samples.

\section{Acknowledgments}

The authors would like to thank the Corpo Forestale dello Stato for the availability and logistic support during the measures in the Reserve. The authors are also grateful 
to Dr. Achille Palma, Metapontum Agrobios, for the soil chemical analyses. This paper was supported by MIUR in the framework of "Tecnologie per le Osservazioni della Terra e i Rischi Naturali -TeRN" project (PON 2004-2006; Obiettivo Realizzativo OR2).

\section{References}

[1] V. E. A. Post, "Fresh and saline groundwater interaction in coastal aquifers: is our technology ready for the problems ahead?" Hydrogeology Journal, vol. 13, no. 1, pp. 120-123, 2005.

[2] C. P. Petalas and I. B. Diamantis, "Origin and distribution of saline groundwaters in the upper Miocene aquifer system, coastal Rhodope area, northeastern Greece," Hydrogeology Journal, vol. 7, no. 3, pp. 305-316, 1999.

[3] C. Petalas and N. Lambrakis, "Simulation of intense salinization phenomena in coastal aquifers-the case of the coastal aquifers of Thrace," Journal of Hydrology, vol. 324, no. 1-4, pp. 51-64, 2006.

[4] M. Polemio, P. P. Limoni, D. Mitolo, and F. Santaloia, "Characterisation of the Ionian-Lucanian coastal aquifer and seawater intrusion hazard," in Proceedings of the 17th Salt Water Intrusion Meeting, pp. 422-434, Delft, The Netherlands, 2002.

[5] M. A. Somay and U. Gemici, "Assessment of the salinization process at the coastal area with hydrogeochemical tools and geographical information systems (GIS): Selçuk plain, Izmir, Turkey," Water, Air, and Soil Pollution, vol. 201, no. 1-4, pp. 55-74, 2009.

[6] D. W. Steeples, "Engineering and environmental geophysics at the millennium," Geophysics, vol. 66, pp. 31-35, 2001.

[7] V. Lapenna, P. Lorenzo, A. Perrone, S. Piscitelli, E. Rizzo, and F. Sdao, "2D electrical resistivity imaging of some complex landslides in the Lucanian Apennine chain, southern Italy," Geophysics, vol. 70, no. 3, pp. B11-B18, 2005.

[8] S. Pantelis, M. Kouli, F. Vallianatos, A. Vafidis, and G. Stavroulakis, "Estimation of aquifer hydraulic parameters from surficial geophysical methods: a case study of Keritis Basin in Chania (Crete-Greece)," Journal of Hydrology, vol. 338, no. 1-2, pp. 122-131, 2007.

[9] D. Chianese and V. Lapenna, "Magnetic probability tomography for environmental purposes: test measurements and field applications," Journal of Geophysics and Engineering, vol. 4, no. 1, article 08, pp. 63-74, 2007.

[10] V. Naudet, M. Lazzari, A. Perrone, A. Loperte, S. Piscitelli, and V. Lapenna, "Integrated geophysical and geomorphological approach to investigate the snowmelt-triggered landslide of Bosco Piccolo village (Basilicata, southern Italy)," Engineering Geology, vol. 98, no. 3-4, pp. 156-167, 2008.

[11] R. Balia, E. Gavaudò, F. Ardau, and G. Ghiglieri, "Geophysical approach to the environmental study of a coastal plain," Geophysics, vol. 68, no. 5, pp. 1446-1459, 2003.

[12] A. T. Batayneh, "Use of electrical resistivity methods for detecting subsurface fresh and saline water and delineating their interfacial configuration: a case study of the eastern Dead Sea coastal aquifers, Jordan," Hydrogeology Journal, vol. 14, no. 7, pp. 1277-1283, 2006.

[13] P. Bauer, R. Supper, S. Zimmermann, and W. Kinzelbach, "Geoelectrical imaging of groundwater salinization in the Okavango Delta, Botswana," Journal of Applied Geophysics, vol. 60, no. 2, pp. 126-141, 2006.

[14] M. A. Koukadaki, G. P. Karatzas, M. P. Papadopoulou, and A. Vafidis, "Identification of the saline zone in a coastal aquifer using electrical tomography data and simulation," Water Resources Management, vol. 21, no. 11, pp. 1881-1898, 2007.

[15] S. E. Kruse, M. R. Brudzinski, and T. L. Geib, "Use of electrical and electromagnetic techniques to map seawater intrusion near the Cross-Florida Barge Canal," Environmental and Engineering Geoscience, vol. 4, no. 3, pp. 331-340, 1998.

[16] A. A. Nowroozi, S. B. Horrocks, and P. Henderson, "Saltwater intrusion into the freshwater aquifer in the eastern shore of Virginia: a reconnaissance electrical resistivity survey," Journal of Applied Geophysics, vol. 42, no. 1, pp. 1-22, 1999.

[17] S. S. Abdul Nassir, M. H. Loke, C. Y. Lee, and M. N. M. Nawawi, "Salt-water intrusion mapping by geoelectrical imaging surveys," Geophysical Prospecting, vol. 48, no. 4, pp. 647661,2000

[18] M. Sherif, A. El Mahmoudi, H. Garamoon, and A. Kacimov, "Geoelectrical and hydrogeochemical studies for delineating seawater intrusion in the outlet of Wadi Ham, UAE," Environmental Geology, vol. 49, no. 4, pp. 536-551, 2006.

[19] A. Cimino, C. Cosentino, A. Oieni, and L. Tranchina, "A geophysical and geochemical approach for seawater intrusion assessment in the Acquedolci coastal aquifer (Northern Sicily)," Environmental Geology, vol. 55, no. 7, pp. 1473-1482, 2008.

[20] M. H. Khalil, "Geoelectric resistivity sounding for delineating salt water intrusion in the Abu Zenima area, west Sinai," Egypt Journal of Geophysics and Engineering, vol. 3, pp. 243-251, 2006.

[21] D. W. Urish and R. K. Frohlich, "Surface electrical resistivity in coastal groundwater exploration," Geoexploration, vol. 26, no. 4, pp. 267-289, 1990.

[22] A. A. M. Ebraheem, M. M. Senosy, and K. A. Dahab, "Geoelectrical and hydrogeochemical studies for delineating groundwater contamination due to salt-water intrusion in the northern part of the Nile Delta, Egypt," Ground Water, vol. 35, no. 2, pp. 216-222, 1997.

[23] K. Choudhury and D. K. Saha, "Integrated geophysical and chemical study of saline water intrusion," Ground Water, vol. 42, no. 5, pp. 671-677, 2004.

[24] G. Spilotro, F. Canora, F. Caporale, G. Leandro, and N. Vignola, "Hydrogeology and groundwater salinization in the ionian coastal plane of the Basilicata Region," in Proceedings of the 17th Salt Water Intrusion Meeting, pp. 422-434, Delft, The Netherlands, 2002.

[25] E. Amezketa, "An integrated methodology for assessing soil salinization, a pre-condition for land desertification," Journal of Arid Environments, vol. 67, no. 4, pp. 594-606, 2006.

[26] N. Ciaranfi, M. Maggiore, P. Pieri, L. Rapisardi, G. Ricchetti, and N. Walsh, "Considerazioni sulla neotettonica della Fossa bradanica," in Nuovi Contributi Alla Realizzazione Della Carta Neotettonica d'Italia, vol. 251, pp. 73-96, C.N.R. Progetto Finalizzato Geodinamica, Napoli, Italy, 1979.

[27] M. Tropeano, L. Sabato, and P. Pieri, "The Quaternary "Postturbidite" sedimentation in the South-Apennines Foredeep (Bradanic Trough-Southern Italy)," Italian Journal of Geosciences Bull, vol. 1, pp. 449-454, 2001.

[28] E. Valpreda and U. Simeoni, "Assessment of coastal erosion susceptibility at the national scale: the Italian case," Journal of Coastal Conservation, vol. 9, no. 1, pp. 43-48, 2003.

[29] B. M. S. Giambastiani, M. Antonellini, G. H. P. Oude Essink, and R. J. Stuurman, "Saltwater intrusion in the unconfined coastal aquifer of Ravenna (Italy): a numerical model," Journal of Hydrology, vol. 340, no. 1-2, pp. 91-104, 2007.

[30] A. Satriani, A. Loperte, T. Simoniello, M. D’Emilio, C. Belviso, and V. Lapenna, "A multidisciplinary approach for studying 
the forest reserve of Metapontum (southern Italy) affected by saltwater intrusion phenomena," EGU Geophysical Research Abstracts, vol. 9, 2007.

[31] M. H. Loke and R. D. Barker, "Rapid least-squares inversion of apparent resistivity pseudosections by a quasi-Newton method," Geophysical Prospecting, vol. 44, no. 1, pp. 131-152, 1996.

[32] Y. Sasaki, "Resolution of resistivity tomography inferred from numerical simulation," Geophysical Prospecting, vol. 40, no. 4, pp. 453-463, 1992.

[33] A. Perrone, G. Zeni, S. Piscitelli et al., "Joint analysis of SAR interferometry and electrical resistivity tomography surveys for investigating ground deformation: the case-study of Satriano di Lucania (Potenza, Italy)," Engineering Geology, vol. 88, no. 3-4, pp. 260-273, 2006.

[34] D. S. Parasnis, Principle of Applied Geophysics, Chapman \& Hall, London, UK, 1986.

[35] W. De Breuk and G. De Moor, "The water table acquifer in the eastern coastal area of Belgium," Bulletin of the International Association of Scientific Hydrology, vol. 14, pp. 137-155, 1969.

[36] A. A. R. Zohdy, P. Martin, and R. J. Bisdorf, "A study of seawater intrusion using direct-current soundings in the southeastern part of the Oxnard Plain, California," Open-File Report 93-524, Geological Survey, 1993.

[37] Soil Survey Division Staff, Soil Survey Manual USDA Agric Handbook 18, U.S. Government Printing Office, Washington, DC, USA, 1993. 

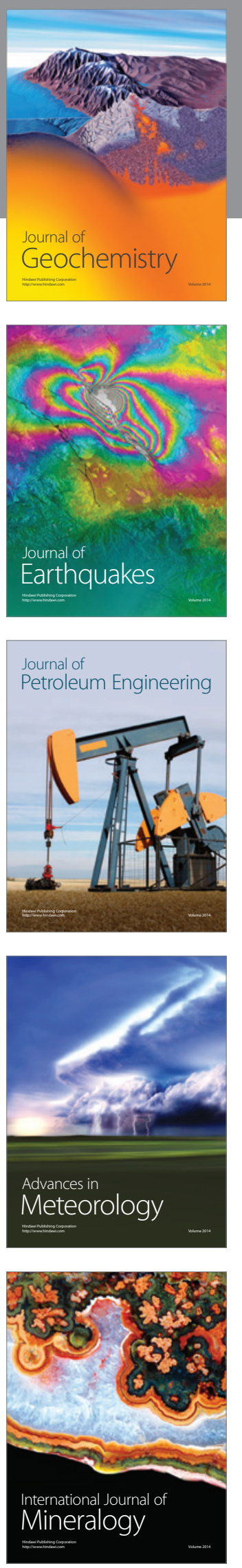
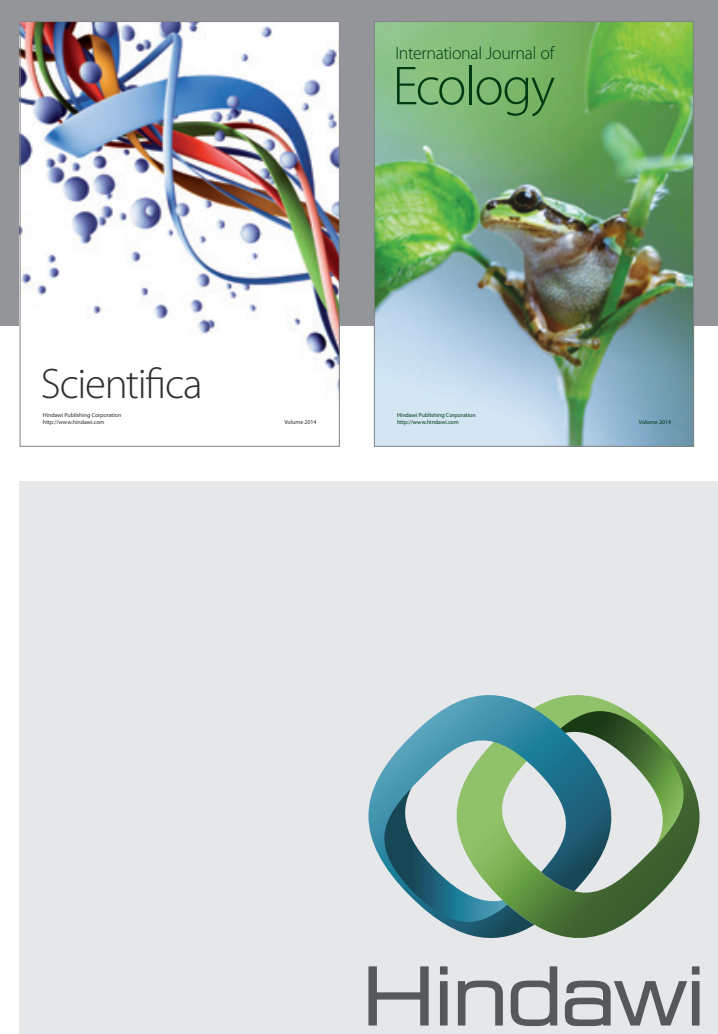

Submit your manuscripts at http://www.hindawi.com
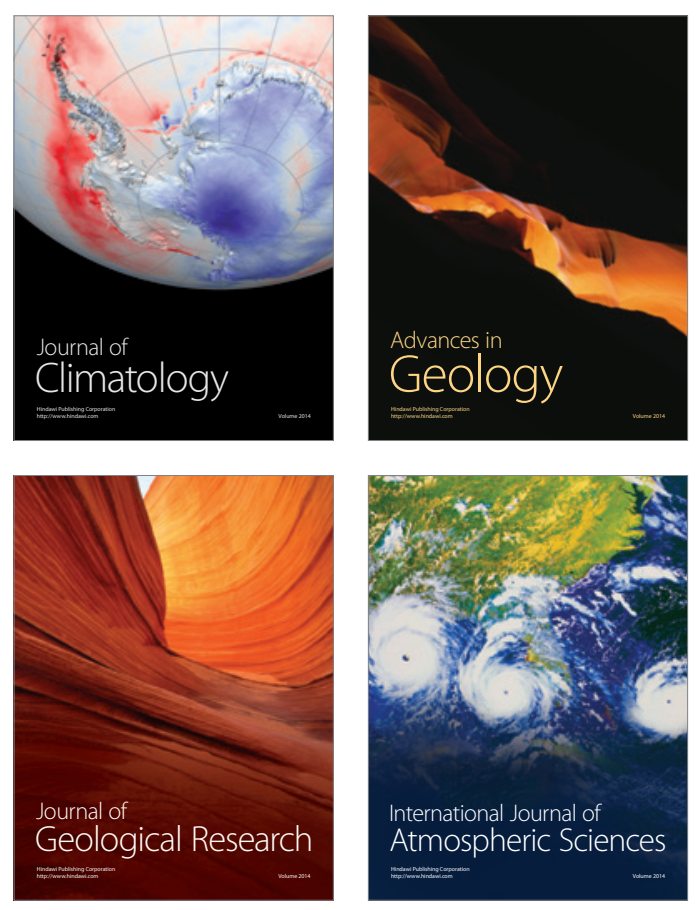
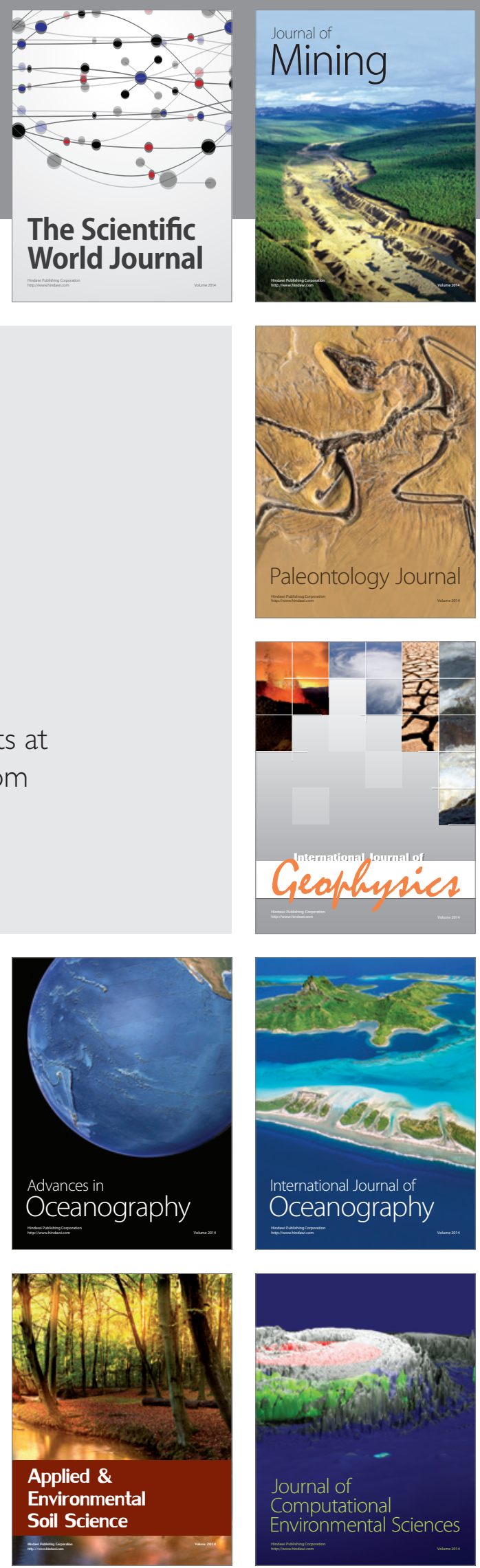